\title{
Prediction of future drawdown of water levels of the Pleistocene aquifer system of Wadi El-Assiuti Area, Eastern Desert, Egypt, as a criterion for management and conservation
}

\author{
Hossam Hamdy Elewa* \\ Water Division, National Authority for Remote Sensing \\ and Space Sciences (NARSS), 23 Josef Brows Tito Street, Cairo 11769, Egypt
}

\section{A R T I C L E I N F O}

\section{Article history:}

Received 13 January 2006

Received in revised form 24 March 2008

Accepted 26 March 2008

\section{Keywords:}

Egypt

Eastern desert

Wadi (dry valley) El-Assiuti

Pleistocene aquifer

Flow net map

Scenarios of water levels drawdown

\begin{abstract}
A B S T R A C T
Wadi El-Assiuti designates a remarkable dry drainage basin in Middle Egypt. The Pleistocene groundwater aquifer of this area represents the main water source used for reclamation and domestic purposes.

The increasing number of groundwater wells drilled at the entrance of Wadi El-Assiuti in recent years, with its consequent over consumption of the groundwater reservoir, seems to be the clear-cut cause for groundwater levels drawdown and quantity deterioration. The constructed flow net map for the Pleistocene aquifer system sketched a pattern of piezometric pressures and flow directions. The regional water flow is from east-northeast towards west-southwest directions, with some adverse minor directions at the north-central part of the study area. This map declared the areas suffering from over pumping (piezometric lows).

However, using empirical formulae and assumptions, the expected drop of piezometric levels of groundwater in the Pleistocene aquifer, as future scenarios, was predicted for 5, 10 and 20 years. These future scenarios reflected the urgent need for a policy or management scheme to decrease the severe drawdown of water level in this important developmental area.
\end{abstract}

(C) 2008 Published by Elsevier B.V.

\section{Introduction}

The study area lies on the eastern bank of the Nile River, northeast of Assiut and extends to the east through Wadi El-Assiuti. The catchment basin of Wadi El-Assiuti is situated entirely in the elevated Maaza Eocene limestone plateau that forms a distinctive landscape feature in the desert east of the Nile Valley (Fig. 1c and d). The region under investigation covers an area of about $2700 \mathrm{~km}^{2}$, located between latitudes $27^{\circ} 00^{\prime} \mathrm{N}$ and $27^{\circ} 30^{\prime} \mathrm{N}$ and longitudes $31^{\circ} 00^{\prime} \mathrm{E}$ and $31^{\circ} 30^{\prime} \mathrm{E}$ (Fig. 1a).

The increase of newly reclaimed areas for agriculture and the fast growth of newly established settlements in the Assiut Governorate, Middle Egypt, are accompanied by growing activities in searching for new water resources. Wadi El-Assiuti is one of the largest wadis in Middle Egypt, with a remarkable dry drainage basin, whose main channel reach about $186 \mathrm{~km}$ in length. It includes potential soils for agricultural development if irrigation water is available.

\footnotetext{
* Tel.: +20 2 6225834; fax: +2026225800

E-mail address: hossh2@yahoo.com.
}

The Pleistocene sediments of Wadi El-Assiuti, the main groundwater aquifer, are mostly influenced by the Nile River recharge and to a less extent by the surface runoff water from the Eastern Desert valleys. Farthest inside the eastern tributaries of Wadi El-Assiuti, the influence of the Nile River diminishes, and the main recharging sources are those coming from the upward leakage from older formations or from the rainfalls of the Red Sea mountain range, outcropping to the east.

The study area represents a part of the arid belt of North Africa, which is characterized by hot, dry and rainless climate in summer and being mild with rare rainfall in winter. Locally, the area is characterized by semiarid to arid climatic conditions. The maximum monthly mean value was $36.7^{\circ} \mathrm{C}$ (August 1980), while the minimum value is $10.36^{\circ} \mathrm{C}$ (January 1983). The mean monthly value of the relative humidity over the area is $37.8 \%$. This value reaches $55 \%$ in the winter times and decreases to less than $21 \%$ in the summer periods. Rainfall is generally negligible. The amount of rainfall in the study area is not significant all over the year. Sometimes during the winter season, occasional short rainy storms take place over some scattered locations. During a period from 1975 to 1989, rains occurred during 24 days, with a maximum monthly mean value of $5 \mathrm{~mm}$. The maximum-recorded monthly mean value of wind velocity is 

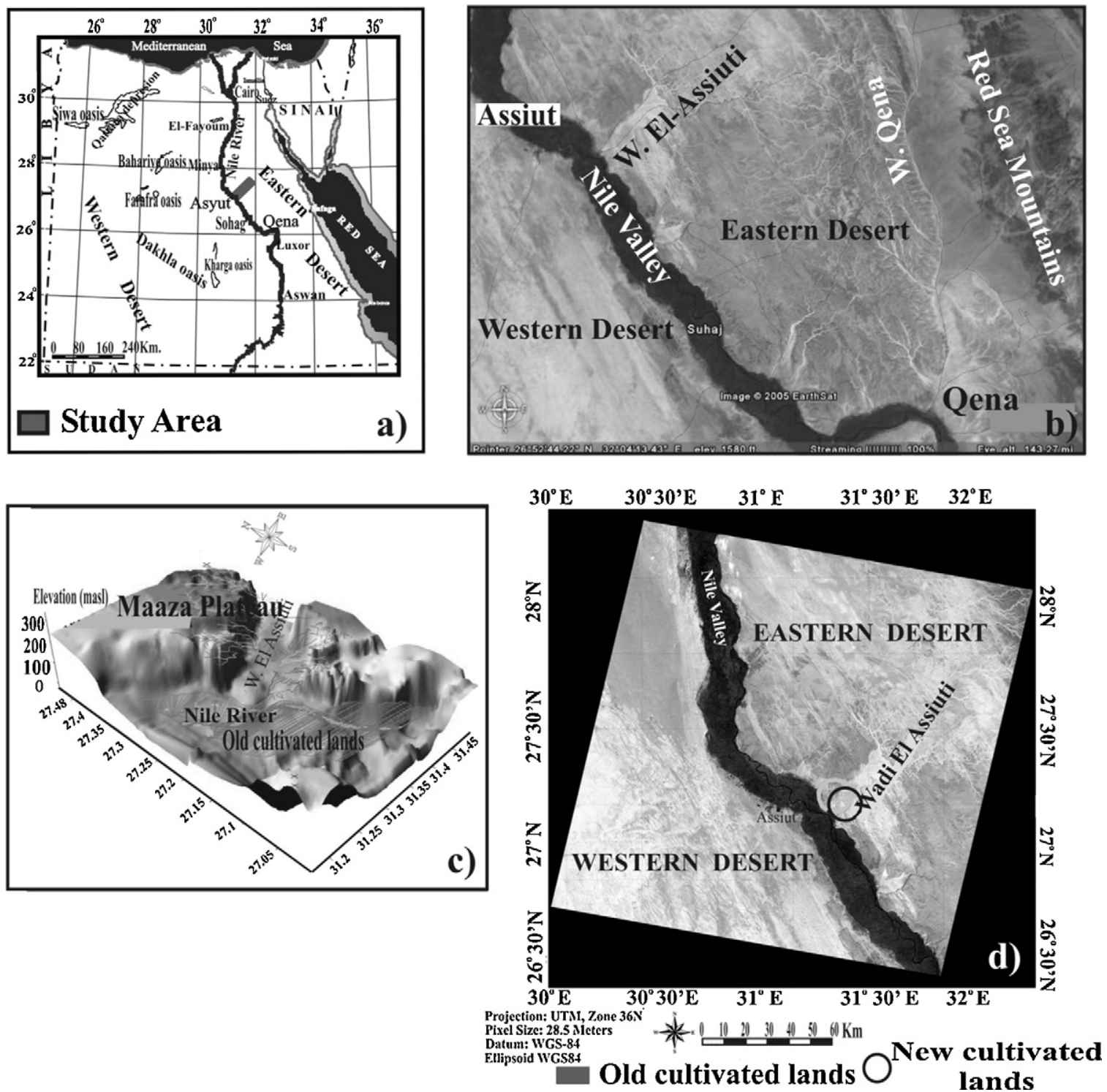

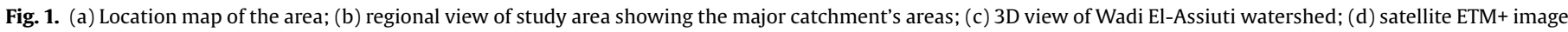
(band composition 742,2000 ).

$19.431 \mathrm{~cm} / \mathrm{h}$ (April 1981). The minimum value is $7.8 \mathrm{~km} / \mathrm{h}$ (February 1977).

\subsection{Methodologies and approaches}

The author of the present work principally investigated a research project performed and funded by the National Authority for Remote Sensing and Space Sciences (NARSS, 2005). One of the main objectives of this project was the integration of remote sensing and geographical information system "GIS" as useful tools and data base that could be useful in proper decision making and successful investigation of groundwater resources. The hydrogeological investigations for determining the Pleistocene aquifer characteristics; its geometry, thickness, water depths and levels, hydraulic parameters and geographic positioning system (GPS) for determining wells locations were stored in digital maps or overlays in GIS to predict the future water levels drawdown scenarios of the Pleistocene aquifer system of Wadi El-Assiuti area. Consequently, recommendations about the sustainable use and future management items of the aquifer system were presented. Further- more, evaluation of water resources is carried out through using the well-known empirical and analytical relationships.

\section{Geomorphologic and geologic perspectives}

Wadi El-Assiuti runs southwestward from the watershed of the Maaza Plateau to the Nile flood plain, which represents the western limit of the study area. The Precambrian basement rocks, crop out at the extreme eastern part of the study area, east of Wadi Qena which bounds the main catchment area of Wadi El-Assiuti channels (Fig. 1b). However, this catchment area may form the main source of recharging for the Pleistocene groundwater. To the east and northeast of the channels of Wadi Qena, Paleozoic (Cambrian to Carboniferous) and Mesozoic (Jurassic and Cretaceous) rocks crop out whereas to the west of it (directly east of Wadi El-Assiuti) Cretaceous and Eocene rocks form the main succession there. On the other hand, western parts of the study area are mainly covered by the carbonates of lower and middle Eocene. Plio-Pleistocene and Recent sediments cover mainly the wadies (the entrance of Wadi El-Assiuti) (EGS, 1979, 1983). 


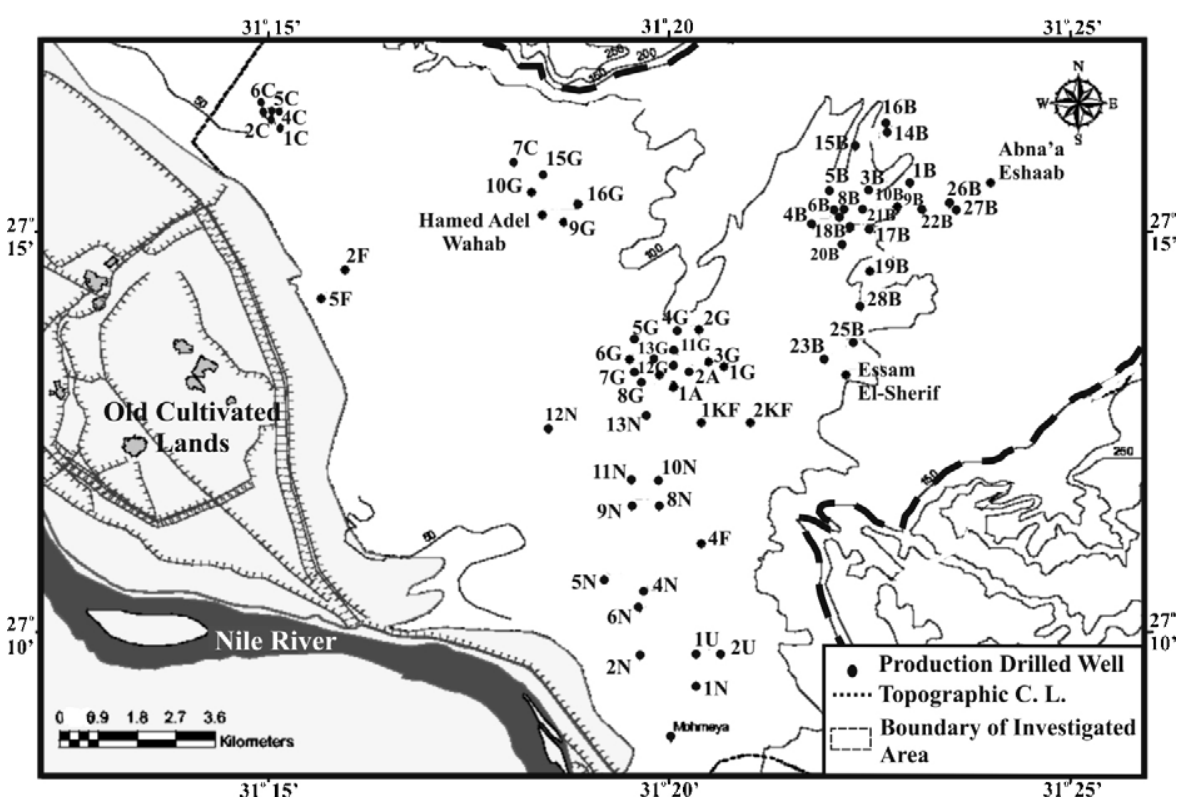

Fig. 2. Location map of production wells in Wadi El-Assiuti.

\section{Hydrogeological setting}

The previous studies about Wadi El-Assiuti proved the existence of prolific aquifer system in the Quaternary sediments. During the past 30 years, the groundwater occurrence and the aquifer lithology of Wadi El-Assiuti area were described by many authors, among them: Bakheit (1983), Bakheit et al. (1992), Mousa et al. (1993), Abu El-Ella (1999), Yan et al. (2004) and others.

Historically speaking, nine wells were drilled by Assiut Governorate during the period from 1992 to 1996, having depths ranging between 171 and $235 \mathrm{~m}$. They partially penetrated the Pleistocene aquifer successions. Pumping tests were performed for all wells by the GARPAD (1995). Later on, the number of drilled water wells increased to become about 85 water wells, especially with the involvement of the private sector into the development activities (Fig. 2).
The Assiuti hydrologic system comprises two flow components: the surface water drainage system and the groundwater flow system.

The obtained results refer to the presence of two aquifers in the study area; the Quaternary and the Eocene Carbonate aquifers (lower Eocene). The present work investigates the Quaternary aquifer (early Pleistocene), which is the main aquifer in the study area. The Pleistocene groundwater is abstracted from two water-bearing horizons. They comprise downwards the Issawia Formation and the Armant Formation of the Early Pleistocene times (Fig. 3).

\subsection{The hydraulic characteristics of the aquifer system}

The hydraulic characteristics were estimated from carrying out the field pumping tests on nine wells in the study area. These tests

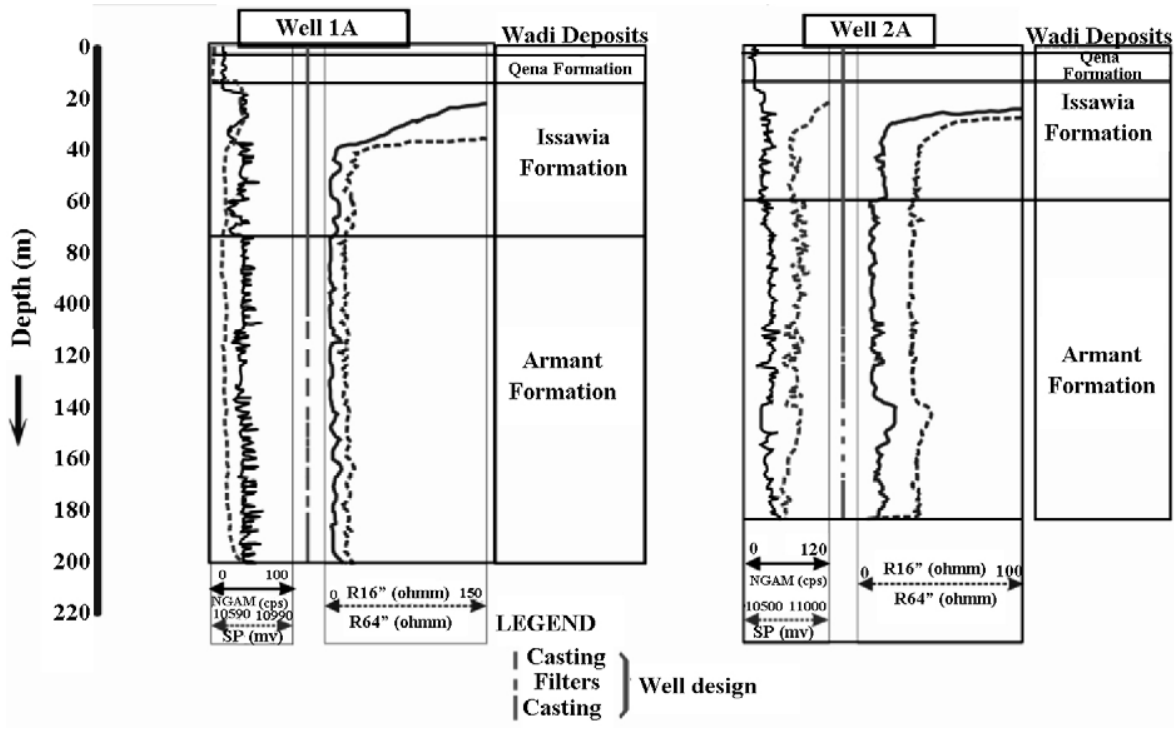

Fig. 3. Interpreted well logging measured curves for Wadi El-Assiuti Well nos. 1A and 2A. 

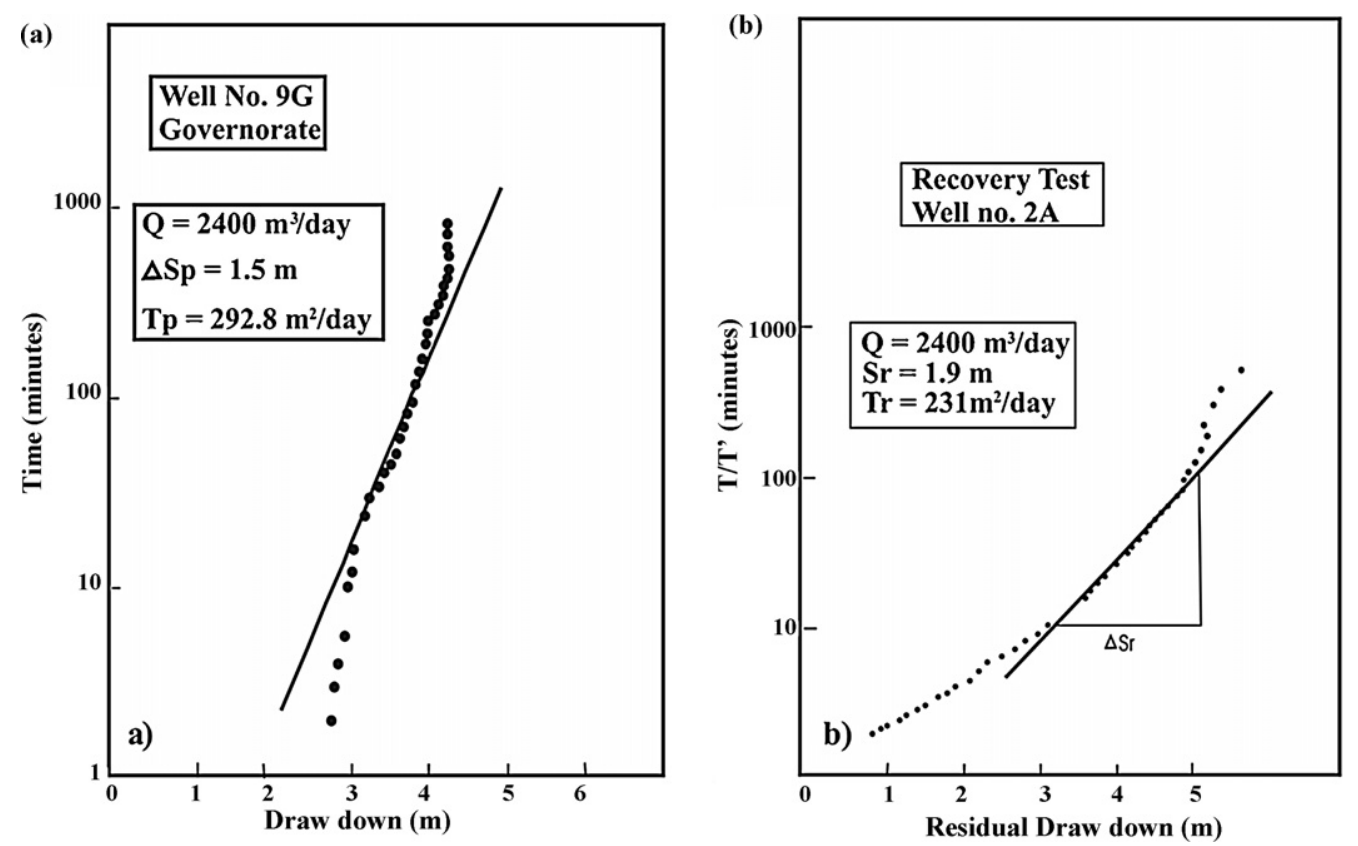

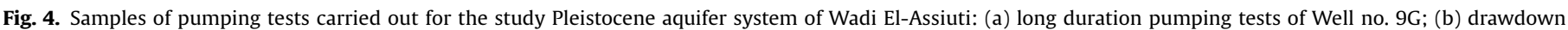
recovery test of Well no. $2 \mathrm{~A}$.

include the constant discharge tests, the step drawdown tests and the recovery tests.

The duration of constant discharge test lasted $24 \mathrm{~h}$, while the step drawdown tests were performed through three stages with different pumping rates. The measurements were carried out using the Hantush-Jacob's method (1955) (Kruseman and de Ridder, 1990):

$S=\left(\frac{Q}{4 \pi T}\right) W(u, r / B)$

where $W(u, r / B)$ is the tabulated well function (long-term drawdowns), $S$ is the coefficient of storage (storativity) (dimensionless) and $T$ is the transmissivity $\left(\mathrm{m}^{2} /\right.$ day).

The aquifer and well losses were obtained from the following equation of Jacob (1947) (Kruseman and de Ridder, 1990):

$S=B Q+C Q^{2}$

where $S$ is the anticipated drawdown in meter, $Q$ is the pumping rate $\left(\mathrm{m}^{3} /\right.$ day), $B$ is the formation drawdown coefficient (day $/ \mathrm{m}^{2}$ ) (due to aquifer properties) and $C$ is the well loss coefficient $\left(\mathrm{day}^{2} / \mathrm{m}^{5}\right)$, which is constant for a given flow rate (due to well design and degree of well development).

The first term in Eq. (2) (BQ) describes the linear component of the drawdown; i.e., the part in which doubling the pumping rate doubles the drawdown. The second term $\left(C Q^{2}\right)$ describes what is often called the "well losses"; the non-linear component of the drawdown. To quantify this, it is necessary to pump the well at several different flow rates (commonly called steps). Rorabaugh (1953) added to this analysis by making the exponent an arbitrary power (usually between 1.5 and 3.5 ).

On the other hand, well efficiency is determined from this sort of test, this is a percentage indicating the fraction of total observed drawdown in a pumped well which is due to aquifer losses (as opposed to being due to flow through the well screen and inside the borehole), using the following relation (derived from Eq. (2)):

$\psi=\frac{B Q}{B Q+C Q^{2}}$

where $\psi$ is the well efficiency and $Q, B$, and $C$ are as defined above.

The obtained results from the constant, step drawdown and recovery tests reflect the following (Table 1 and Fig. 4):

(1) The transmissivity values range between $204.3 \mathrm{~m}^{2} /$ day (Well $12 \mathrm{G}$ ) and $510.7 \mathrm{~m}^{2} /$ day (Well $15 \mathrm{G}$ ). The higher values are recorded at the northwestern part of the area of study (Fig. 5), with the increase in hydraulic gradient due south-southeast. This is attributed mainly to the increase of clay content (Fig. 3).

Table 1

Average results of pumping tests in Wadi El-Assiuti, Assiut Area, Eastern Desert, Egypt (based on Hantush-Jacob's method, 1955 and Bruggeman method, 1966)

\begin{tabular}{|c|c|c|c|c|c|c|c|}
\hline \multirow[t]{2}{*}{ Well no. } & \multicolumn{3}{|c|}{ Aquifer parameters } & \multirow{2}{*}{$\begin{array}{l}\text { Formation loss coefficient } \\
(B)\left(\times 10^{-3} \text { day } / \mathrm{m}^{2}\right)\end{array}$} & \multirow{2}{*}{$\begin{array}{l}\text { Well loss coefficient } \\
\text { (C) }\left(\text { day }^{2} / \mathrm{m}^{5}\right)\end{array}$} & \multirow{2}{*}{$\begin{array}{l}\text { Optimum yield } \\
\text { ( } \mathrm{m}^{3} / \text { day) }\end{array}$} & \multirow{2}{*}{$\begin{array}{l}\text { Well efficiency } \\
(\%) \text { at }\left(70 \mathrm{~m}^{3} / \mathrm{h}\right)\end{array}$} \\
\hline & $\begin{array}{l}\text { Transmissivity } \\
\left(\mathrm{m}^{2} / \text { day }\right)\end{array}$ & $\begin{array}{l}\text { Hydraulic conductivity } \\
\text { (m/day) }\end{array}$ & $\begin{array}{l}\text { Storativity } \\
\left(\times 10^{-3}\right)\end{array}$ & & & & \\
\hline $9 \mathrm{G}$ & 293 & 5.43 & 2.3 & 0.63 & $2.8 \times 10^{-7}$ & 1920 & 53.96 \\
\hline $12 \mathrm{G}$ & 204.3 & 2.55 & 1.3 & 1.9 & $4.56 \times 10^{-7}$ & 2160 & 68.46 \\
\hline $1 \mathrm{~A}$ & 219.6 & 3.66 & 1.6 & 7.9 & $1.17 \times 10^{-7}$ & 2400 & 96.03 \\
\hline $15 G$ & 510.7 & 6.90 & 2.6 & 0.92 & $2.66 \times 10^{-7}$ & 2160 & 64.3 \\
\hline $14 \mathrm{G}$ & 220 & 5.79 & 2.4 & 3.16 & $0.91 \times 10^{-7}$ & 2880 & 94.76 \\
\hline $2 \mathrm{~A}$ & 439 & 10.71 & 3.78 & 2.92 & $3.87 \times 10^{-7}$ & 2640 & 79.72 \\
\hline 15B & 420 & 7.50 & 2.45 & 2.07 & $9.70 \times 10^{-7}$ & 1920 & 52.64 \\
\hline $16 \mathrm{G}$ & 300 & 4.29 & 2.85 & 1.03 & $6.30 \times 10^{-7}$ & 1920 & 45.99 \\
\hline $17 \mathrm{G}$ & 340 & 6.94 & 3.84 & 2.20 & $1.1 \times 10^{-6}$ & 1920 & 50.79 \\
\hline
\end{tabular}




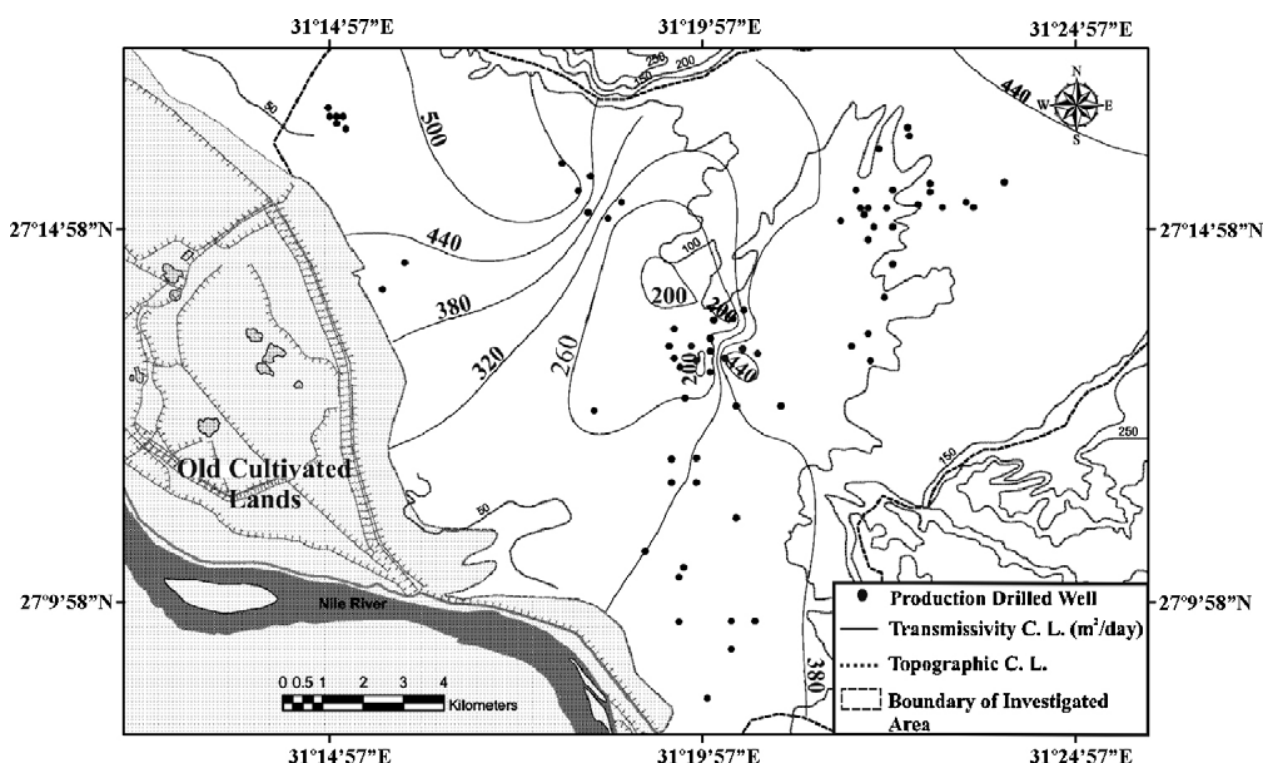

Fig. 5. Transmissivity ( $T$ ( $\mathrm{m}^{2} /$ day) map of the Pleistocene aquifer system of Wadi El-Assiuti.

(2) The hydraulic conductivity values range between $2.55 \mathrm{~m} /$ day (Well 12G) and $10.71 \mathrm{~m} /$ day (Well 2A). The lowest values are recorded at Well 12G (Fig. 6).

(3) At the area of study, the storativity, ranges between $1.3 \times 10^{-3}$ (Well 12G) and $3.84 \times 10^{-3}$ (Well 17G). These values reflect semi-confined conditions for the local aquifer in the studied area.

(4) The calculated formation loss ranges between $0.63 \times 10^{-3}$ day/ $\mathrm{m}^{2}$ (Well 9G) and $7.9 \times 10^{-3} \mathrm{day} / \mathrm{m}^{2}$ (Well 1A). The well loss varies from $0.91 \times 10^{-7} \mathrm{day}^{2} / \mathrm{m}^{5}$ (Well 14G) to $9.7 \times 10^{-7} \mathrm{day}^{2} / \mathrm{m}^{5}$ (Well 15G)

(5) The well efficiency (\%) of wells at discharge $80 \mathrm{~m}^{3} / \mathrm{h}$ ranges between 45.99 (Well 16G) and 96.03 (Well 1A).

(6) Safe yield value for all wells reach $70 \mathrm{~m}^{3} / \mathrm{h}$. This value was assessed for the boreholes by step drawdown pump test. The test was conducted continuously for $8 \mathrm{~h}$. Each step has $2 \mathrm{~h}$ and the tests are started at a low step $25 \%$ of design capacity and increased in four incremental steps such as 50, 75 and $100 \%$ of capacity. The drawdowns were noted for the entire period. Aquifer properties like transmissivity and storativity are found out by constant and recovery methods. Well loss and formation loss coefficient were also calculated. These values are made use in assessing safe yield of the bore well. However, the estimated safe yield is a little bit higher than the practical used one in the study area.

(7) Also, from the data of step drawdown tests, the general well equation was deduced.

\subsection{Pleistocene aquifer thickness variation}

In the study area, the tested useful thickness of the aquifer ranges between $42.5 \mathrm{~m}$ (Well Abna'a Eshaab) and $77 \mathrm{~m}$ (Well 5F). It increases generally from east to west direction (Fig. 7). However, in an area wise concept, the Pleistocene aquifer tested useful thickness is spatially varies from being maximum near to the Nile cultivated plain at the downstream of Wadi El-Assiuti, and decreases towards

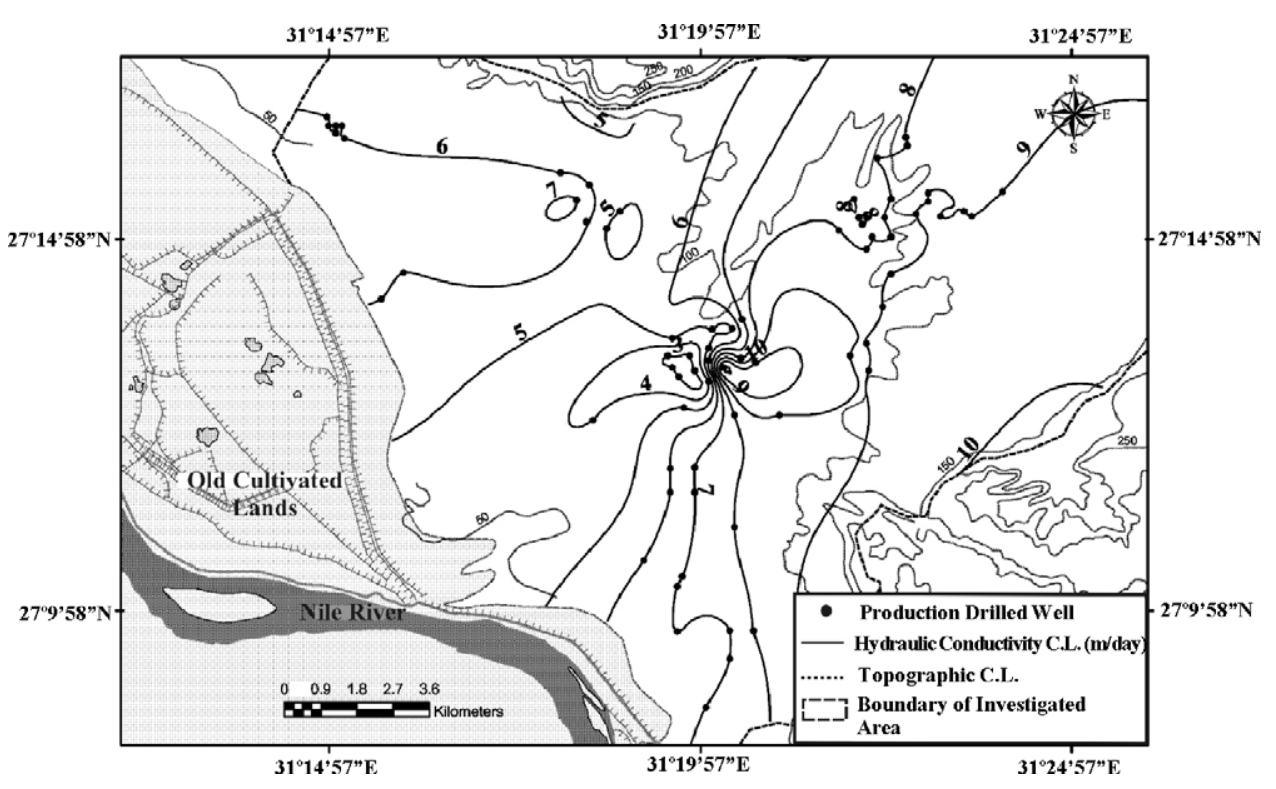

Fig. 6. Hydraulic conductivity (K) (m/day) map of the Pleistocene aquifer system of Wadi El-Assiuti. 


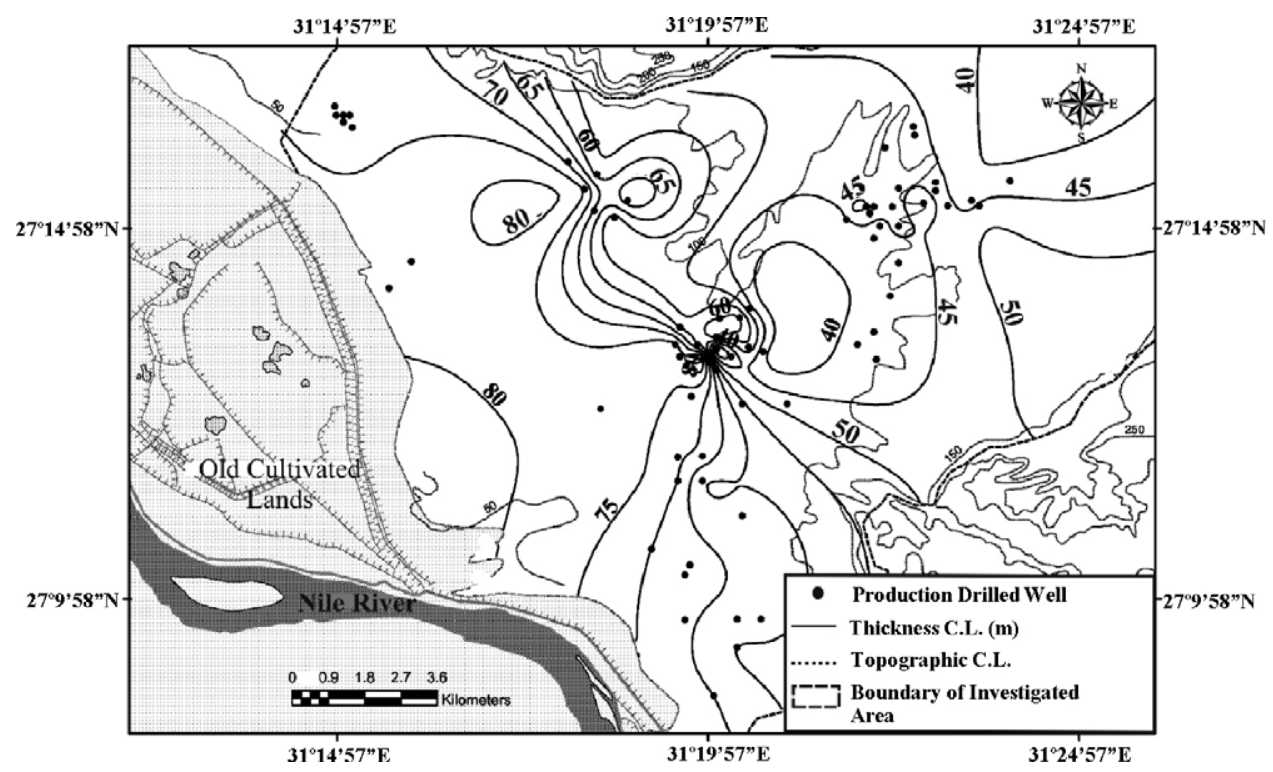

Fig. 7. Tested useful thickness of the Pleistocene aquifer system.

the upstream (i.e., the thickness increases westwards towards the River Nile).

\subsection{Pleistocene equipotentiometric characteristics}

The depth to water (from ground surface) is topographically controlled. The groundwater is available at depths ranging between $27.5 \mathrm{~m}$ (Well 5F) and 44.2 m (Well Abna'a Eshaab) below ground surface.

The measured water-table elevations (with reference to sea level), for the network of wells drilled in the semiconfined Pleistocene aquifer (hydraulically connected Issawia and Armant water-bearing formations) led to the construction of an equipotentiometric surface contour map (flownet map), using ARC GIS software. Contours are interpolated between the measured water-table elevations, and the flow lines are drawn at right angles to these equipotential lines (Fig. 8).

The constructed equipotentiometric surface contour map for the Pleistocene aquifer system in the area of study reflects the following results:

(1) The equipotentiometric surfaces ( $\mathrm{masl}$ ) are topographically controlled and vary from $57.5 \mathrm{~m}$ (Well 5F) to $74 \mathrm{~m}$ (Well Abna'a Eshaab).

(2) From the map of equipotentiometric surface, we consider quantitatively some of the simplest classes of groundwater flow in two dimensions and with no fluctuations in time. The method described below gave accurate and useful answers for many purposes. The map was also useful to be able to calculate a maximum value for the groundwater discharge or flow rate, or to sketch a pattern of pressures and flow directions within the Pleistocene aquifer.

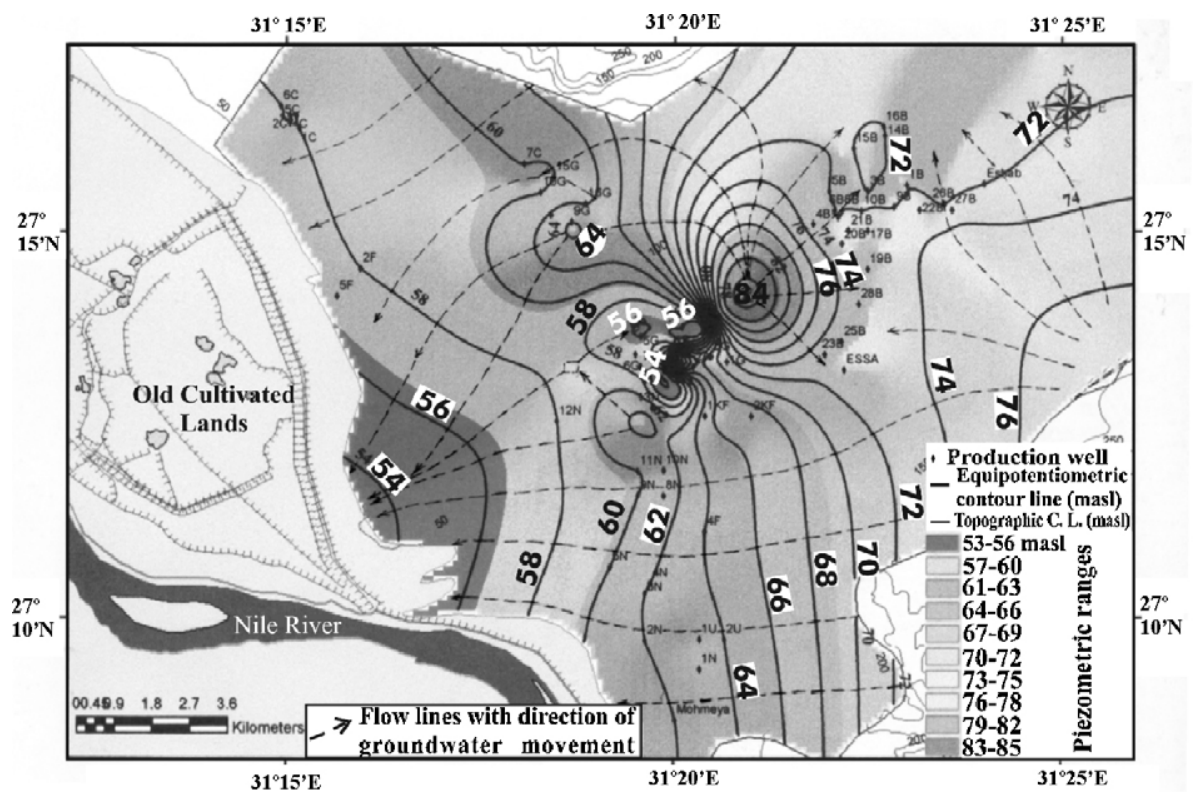

Fig. 8. Flownet map of the Pleistocene aquifer system of Wadi El-Assiuti. 


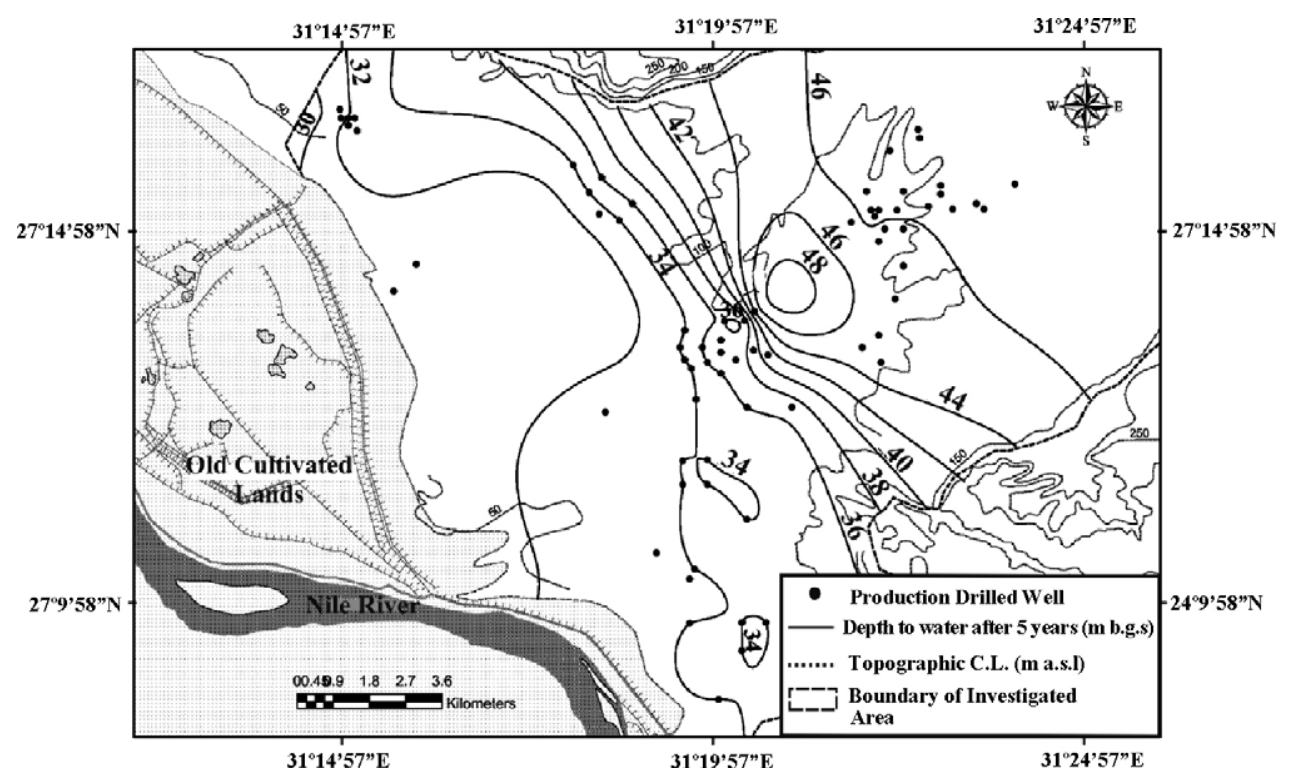

Fig. 9. Future scenario of the expected water depth after 5 years of operation (year 2010 ) (at $70 \mathrm{~m}^{3} / \mathrm{h}$ ).

The annual discharge or flow rate of the groundwater aquifer in the area of study is calculated by applying the following equation of Darcy's law:

$Q=K I A$

where $Q$ is the discharge rate through an area $A ; A$ is the crosssectional area normal to the direction of flow. $I$ is the hydraulic gradient; $K$ is the hydraulic conductivity of the material.

However, Darcy's law may also be written in the form:

$Q=T I W$

where $T$ is the transmissivity ( $T=K D$, where, $K$ is the hydraulic conductivity and $D$ is the total thickness), $W$ is the width of area (m) and $I$ is the hydraulic gradient $(\Delta h / \Delta l)$, where $\Delta h$ is the difference in head $(\mathrm{m})$ and $\Delta l$ is the difference between measured points in the direction of flow $(\mathrm{m})$.
The regional water flow is from the east-northeast to the west-southwest, with some adverse minor directions at the northcentral part of the study area, attributed to the structural-bearing and the consumption rates of this part of Wadi El-Assiuti. These structural elements exhibit groundwater flow boundaries, and cause a set of flow field conditions. It is also clear that the flow lines are strongly constrained to parallel the boundaries of the aquifer system of the study area, represented by the limestone plateau (Figs. 1c and 8). Thus, the topographic divides represented by the limestone plateau (Middle Eocene) appear to be groundwater divides as well as the limestone succession continues downward in the subsurface. This being the obvious result, when the water table is a subdued replica of the topography. That is to say, no flow crosses the topographic boundary of the limestone plateau, into or out of the region. This fact is concluded from the fact that a non-flowing boundary must be aligned at right angles to the equipotential lines and must therefore be collinear with the lines

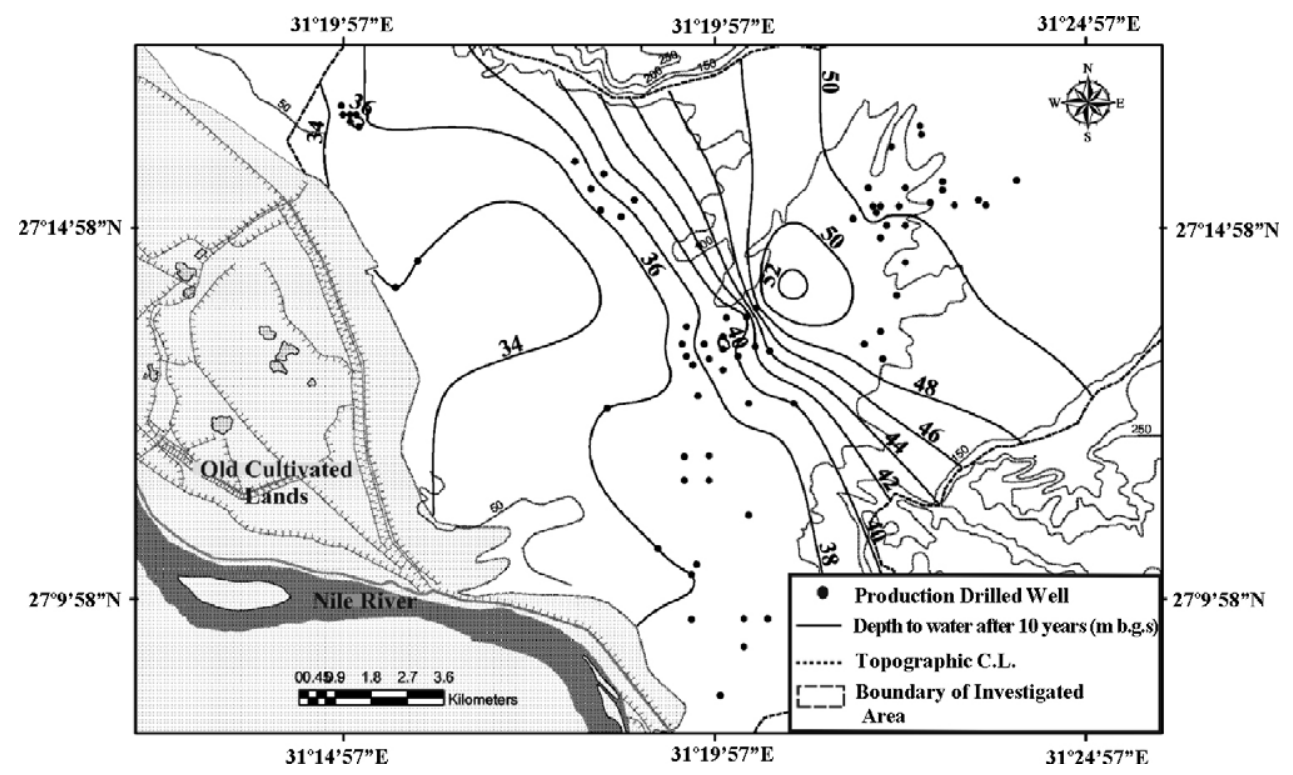

Fig. 10. Future scenario of the expected water depth after 10 years of operation (year 2015) (at $70 \mathrm{~m}^{3} / \mathrm{h}$ ). 
of flow (Domenico and Schwartz, 1990). Fig. 8 shows that there is also a real impermeable layer, represented by the Pliocene clays at some depth in the region. This impermeable layer is likewise a non-flowing boundary. However, the constructed equipotentiometric map of the study area reflects the present-day status of the Pleistocene aquifer system, where the equipotentiometric values and groundwater flow depend mainly on the degree of water consumption and boundary conditions.

In fact, the most important information provided by the equipotentiometric map (Fig. 8) is the determination of areas suffering from over pumping (piezometric lows). These areas are encountered at the central part of the study area, represented by closed contours (contours 54 and 56). These areas are occupied by a great number of wells drilled in its vicinity. The areas of low piezometric values are symptoms of an exhausted auifer system. The overpumping has its own bearing on the hydraulic gradient of the equipotential lines around these areas, as it became steep. The steep hydraulic gradient is a direct impact of overpumping in these areas, as the flow rate around these areas seems to be accelerated to compensate the over withdrawal of groundwater by these crowded wells. In fact, the equipotentiometric map constructed to illustrate the present piezometric pressures of the Pleistocene aquifer in Wadi El-Assiuti expresses, to a great extent, the mismanagement criteria, as the localization of wells to be drilled neglected the interference drawdown between them, especially when they operate simultaneously.

(3) From the map (Fig. 8), the volumetric flow rate within the flow net can be determined by summing the individual $Q$ 's in each of the flow tubes of Fig. 8. This approach is derived from Darcy's law expressed for one section of a flow channel, as

$$
\Delta Q=K\left(\frac{\Delta b}{L}\right) a
$$

where $\Delta Q$ is the flow rate in one channel, $\Delta b$ is the head drop across a pair of equipotential lines, $L$ is the distance over which the head drop takes place, and $a$ is the distance between adjacent flow lines. For the homogenous isotropic system and its characteristics curvilinear squares, $L=a$. As the total $Q$ in the system is the $\Delta Q$ times the number of flow channels $\left(n_{\mathrm{f}}\right)$, and the total head drop across the flow system $(\Delta H)$ is the $\Delta b$ times the number of head drops $\left(n_{\mathrm{d}}\right)$, the total flow is expressed as

$$
Q=\left(\frac{n_{\mathrm{f}}}{n_{\mathrm{d}}}\right) K \Delta H
$$

The flow rate $Q$ is expressed as the volumetric flow rate per unit time per unit thickness of the flow field.

Within each flow tube, between a pair of flow lines, the values of $\Delta q$ for all the squares could be obtained. The total natural flow rate (natural recharge) of groundwater $(\Delta Q)=18,545,110 \mathrm{~m}^{3} /$ year.

\subsection{Evaluation of aquifer potentials and recommendations}

In order to predict the expected future changes of the pumping conditions, with the consequent drop of water depth, the following different scenarios are proposed in the present work by formulating the following empirical relationships within a Basic Computer Program to forecast the future changes as based on the discharge rate value, the pumping operating hours per day and the depth of pumps after 5, 10 and 20 years.

The actual productivity for all wells located in the area of study per year is calculated as a product of multiplying the following items:

$Q=Q_{1} t d n$

where $Q$ is the actual productivity for all wells ( $\mathrm{m}^{3} /$ year), $Q_{1}$ is the optimum safe yield $\left(70 \mathrm{~m}^{3} / \mathrm{h}\right), t$ is the operating hours ( $10 \mathrm{~h} /$ day $), d$ is the operating days per year (365 days/year) and $n$ is the number of productive wells ( 84 wells).

Thus, the actual productivity $=70 \times 10 \times 365 \times 84=21,462,000 \mathrm{~m}^{3}$ /year. Consequently, the ratio between the total natural recharge of groundwater per year and the actual productivity per year $=(18,545,110 / 21,462,000) \times 100=86.4 \%$.

The interference-drawdown is obtained from the following equation of Lohman (1965), in Kruseman and de Ridder (1990):

$D=\frac{2.3 Q}{4 \pi T} \log \left(\frac{2.25 T t_{\mathrm{o}}}{S r^{2}}\right)$

where $D$ is the interference drawdown (m), $Q$ is the discharge rate ( $\mathrm{m}^{3} /$ day), $T$ is the transmissivity $\left(\mathrm{m}^{2} /\right.$ day), $t_{0}$ is the time of opera-

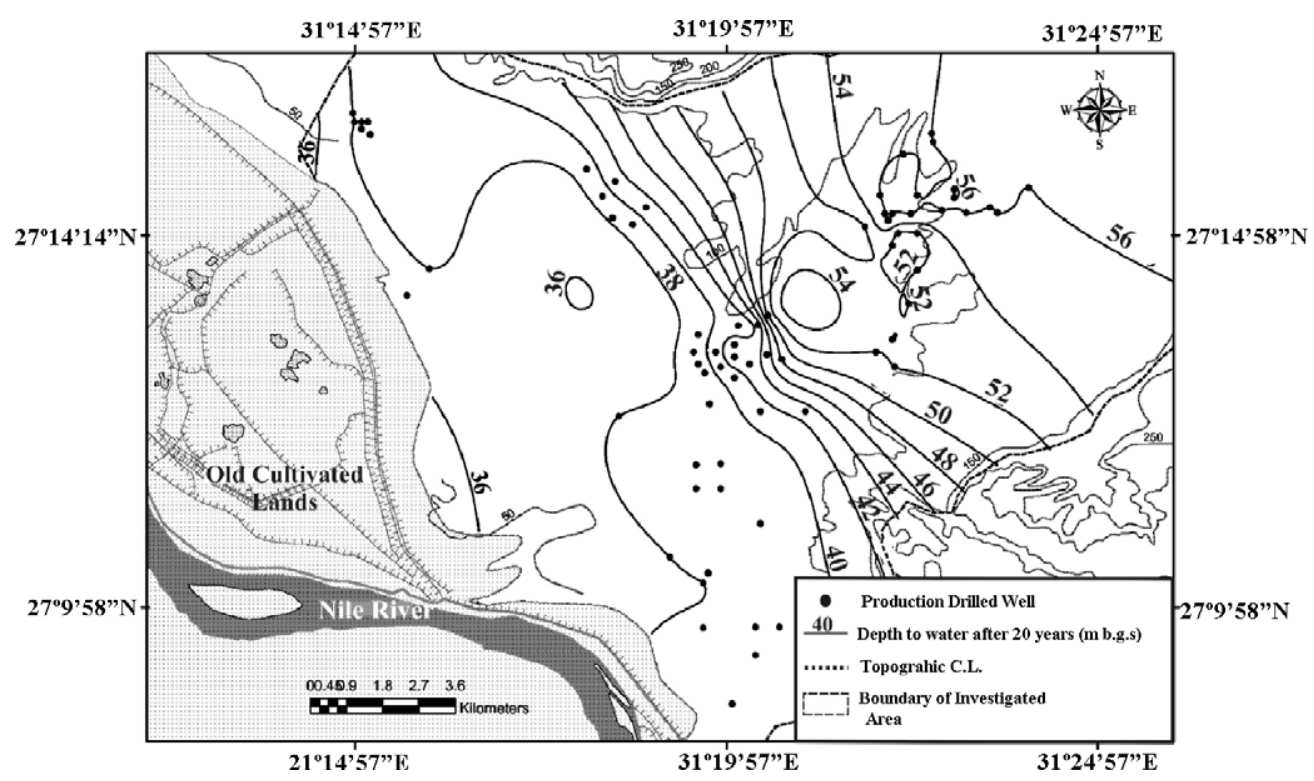

Fig. 11. Future scenario of the expected water depth after 20 years of operation (year 2025) (at $70 \mathrm{~m}^{3} / \mathrm{h}$ ). 
tion (day), $S$ is the storativity (dimensionless) and $r$ is the distance between wells $(\mathrm{m})$.

The self-drawdown for each well separately is evaluated by applying the following equation of Hantush (1964) in Kruseman and de Ridder (1990):

$\mathrm{Sw}=B Q+\left(\frac{\Delta S}{Q}\right)$ average $\log t+C Q^{2}$

where Sw is the self-drawdown ( $\mathrm{m}), Q$ is the pumping rate $\left(\mathrm{m}^{3} /\right.$ day), $B$ is the formation drawdown coefficient (day $/ \mathrm{m}^{2}$ ) (due to aquifer properties), $C$ is the well loss coefficient $\left(\mathrm{day}^{2} / \mathrm{m}^{5}\right.$ ) (due to well design and degree of well development), $t$ is the time of operation (day) and $\Delta S$ is the drawdown increment between the number of step and that precedes it $(\mathrm{m})$.

The maximum depth to groundwater level is obtained from the following equation:

$P=D+\mathrm{Sw}+I$

where $P$ is the maximum depth to groundwater level $(\mathrm{m}), I$ is the initial depth to groundwater level $(\mathrm{m}), D$ is the interferencedrawdown ( $\mathrm{m})$ and $\mathrm{Sw}$ is the self-drawdown ( $\mathrm{m})$.

According to these scenarios, the optimum safe yield and the optimum hours of pumping per day are finally achieved. The investigated optimum safe yield for all productive wells located in the area of study reaches $70 \mathrm{~m}^{3} / \mathrm{h}$, for operating hours of $10 \mathrm{~h} /$ day.

The expected drop of piezometric levels of groundwater in the Pleistocene aquifer after 5, 10 and 20 years of pumping operation with discharge rate of $70 \mathrm{~m}^{3} / \mathrm{h}$ and operations $10 \mathrm{~h} /$ day reflects the following results (Figs. 9-11):

(1) After 5 years of consumption (Fig. 9), the maximum depth to groundwater level (summation of the net drawdown, by considering the natural recharge of $86.4 \%$ of the recommended discharge rate and initial depth to groundwater level) varies from $30.5 \mathrm{~m}$ (Well 5F) to $46.5 \mathrm{~m}$ (Well Abna'a Eshaab). While, after 10 years of consumption (Fig. 10) the level varies from $33.5 \mathrm{~m}$ (Well 5F) to $50.5 \mathrm{~m}$ (Well Abna'a Eshaab). On the other hand, after 20 years of operation (Fig. 11) it ranges between $37 \mathrm{~m}$ (Well 5F) to $56.6 \mathrm{~m}$ (Well Abna'a Eshaab).

(2) The discharge rate of all productive wells of the Business Men Society must be lowered to $70 \mathrm{~m}^{3} / \mathrm{h}$.

(3) The optimum safe yield for all wells located in the area of study is $70 \mathrm{~m}^{3} / \mathrm{h}$ for 10 operating hours per day.

(4) The spacing (interval distance) between each two successive wells should exceed $1 \mathrm{~km}$ in order to minimize the interference drawdown between wells, especially when operating them simultaneously.

It becomes clear that the maximum depth to groundwater level increases towards the east and northeast directions (Figs. 9-11). This increase of the maximum depth to groundwater level in the eastern part of the area of study is attributed to the increase of the initial depth to water and the increasing ground elevation.

\section{Conclusion}

The scenarios of the expected future situation of the Pleistocene Aquifer gave clues about the on-going dramatic over consumption nowaday policy in Wadi El-Assiuti area. The estimated figures about the present and future consumption, compared with the available reserves of groundwater, highlight the need for a better management scheme and for preventing further future drilling of wells near the vicinity of the wells field already present in the study area. Performing a well safe yield of $70 \mathrm{~m}^{3} / \mathrm{h}$, with $10 \mathrm{~h}$ /day operation hours, as an average of each well (but with the operating of these wells alternatively and not simultaneously), may maintain the present productivity life of the aquifer as long as possible.

However, groundwater management programs will provide the dynamic mechanism required to maintain this flow rate, is likewise to give a chance for continuous replenishment by precipitation. Furthermore, the severe drawdown in groundwater depth will increase the pumping costs, which is an economic drawback.

\section{Acknowledgements}

The author greatly appreciate the General Governor of Assiut, who provided the suitable facilities during the field investigations concerning the present work. I am greatly indebted to Prof. Dr. Attef Sherif, Chairman of NARSS, for the financial support of a research project and for giving me the opportunity to principally investigate that project. The project was a trial to make a some sort of contribution along the long road towards setting up a groundwater management scheme for Wadi El-Assiuti important development area.

\section{References}

Abu El-Ella E. Hydrogeochemical evolution of groundwater aquifers in the area east of Assiut Nile Basin, Egypt. Bull Fac Sci, Assiut Univ 1999;28(1-F):1-16.

Bakheit A.A., 1983. Geophsical and geological studies on the entrance of Wadi ElAssiuti, Eastern Desert, Egypt. MSc thesis. Geol. Dept., Assiut Univ.

Bakheit AA, Ibrahim HA, Omran AA, Senosy MA. Groundwater exploration by resistivity method at the entrance of Wadi El-Assiuti, Eastern Desert, Egypt. Bull Fac Sci, Assiut Univ 1992;21(2-F):65-78.

Bruggeman G.A., 1966. Analyse van de bodemconstanten in een grondpakket bestaande uit twee of meer watervoerende lagen gescheiden door semipermeabele lagen. Unpublished research report.

Domenico PA, Schwartz FW. Physical and chemical hydrogeology. 2nd ed. New York: John Wiley \& Sons, Inc.; 1990 [p. 506, Text book].

Egyptian Geological Survey (EGS), 1979. Geological map of Qena quadrangle, Egypt. Scale 1:500.000.

Egyptian Geological Survey (EGS), 1983. Geological map of Gebel El-Urf quadrangle, Egypt. Scale 1:250.000.

General Authority for Rehabilitation Projects and Agricultural Development (GARPAD), 1995. Technical unpublished report about Wadi El-Assiuti groundwater.

Hantush MS. Hydraulics of wells. In: Chow VT, editor. Advances in hydroscience, vol. 1. New York: Academic Press; 1964. p. 281-432.

Hantush MS, Jacob CE. Analysis of data from pumping tests in leaky aquifers. Trans Am Geophys Union 1955;37:702-14.

Jacob CE. Drawdown test to determine effective radius of artesian well. Trans Am Soc Civil Eng 1947;112:1047-64, paper 2321.

Kruseman GP, de Ridder NA. Analysis and evaluation of pumping test data. 2nd ed. Netherlands: Inter. Instit. For Land Recl. Improv (ILRI); 1990, 377 p.

Lohman S., W., 1965. Geology and artesian water supply of the Grand Junction area, Colorado: US Geol. Survey Prof. Paper 451, 149 p.

Mousa SE, Attia FA, El Fotouh A. Geoelectric investigation for groundwater at Wadi El-Asyuti, Egypt. Ain Shams Sci Bull 1993;31:425-39.

National Authority for Remote Sensing and Space Sciences (NARSS), 2005. Water and land resources assessment for the eastern fringes of Assiut District and its adjacent areas, Egypt, using geoinformation technologies. Internal unpublished final report, $253 \mathrm{p}$.

Rorabaugh MJ. Graphical and theoretical analysis of step-drawdown test of artesian well. Proc Am Soc Civil Eng 1953;79 [separate no. 362, 23 p.].

Yan E, Wagdy A, Sultan M, Becker R. Assessment of renewable groundwater resources in the Assiuty hydrologic system of the Eastern Desert, Egypt. In: Second regional conference on Arab water 2004, action plans for integrated development; 2004. p. 1-9. 